IZA DP No. 9261

Is Privatization Working in Ukraine?

New Estimates from Comprehensive Manufacturing

Firm Data, 1989-2013

J. David Brown

John S. Earle

Solomiya Shpak

Volodymyr Vakhitov

August 2015 


\title{
Is Privatization Working in Ukraine? New Estimates from Comprehensive Manufacturing Firm Data, 1989-2013
}

\author{
J. David Brown \\ U.S. Census Bureau and IZA \\ John S. Earle \\ George Mason University, IZA and Central European University \\ Solomiya Shpak \\ George Mason University \\ Volodymyr Vakhitov \\ Kyiv School of Economics \\ Discussion Paper No. 9261 \\ August 2015 \\ IZA \\ P.O. Box 7240 \\ 53072 Bonn \\ Germany \\ Phone: +49-228-3894-0 \\ Fax: +49-228-3894-180 \\ E-mail: iza@iza.org
}

\begin{abstract}
Any opinions expressed here are those of the author(s) and not those of IZA. Research published in this series may include views on policy, but the institute itself takes no institutional policy positions. The IZA research network is committed to the IZA Guiding Principles of Research Integrity.

The Institute for the Study of Labor (IZA) in Bonn is a local and virtual international research center and a place of communication between science, politics and business. IZA is an independent nonprofit organization supported by Deutsche Post Foundation. The center is associated with the University of Bonn and offers a stimulating research environment through its international network, workshops and conferences, data service, project support, research visits and doctoral program. IZA engages in (i) original and internationally competitive research in all fields of labor economics, (ii) development of policy concepts, and (iii) dissemination of research results and concepts to the interested public.
\end{abstract}

IZA Discussion Papers often represent preliminary work and are circulated to encourage discussion. Citation of such a paper should account for its provisional character. A revised version may be available directly from the author. 


\section{ABSTRACT}

\section{Is Privatization Working in Ukraine? New Estimates from Comprehensive Manufacturing Firm Data, 1989-2013*}

This paper estimates the relative multi-factor productivity (MFP) of privatized and stateowned enterprises using a long panel on all initially state-owned manufacturing firms in Ukraine. The large size and length of the time series in the data permit us to track the privatization process and to estimate the impact of privatization within industry-year cells and with controls for firm fixed effects and trends. Results with these methods imply an average $5-10 \%$ relative MFP for majority privatized versus state-owned firms. The gap increases with time since privatization, reaching about $15-17 \%$ five years after privatization. It also increases with calendar time although recent privatizations are associated with smaller relative MFP. We find no evidence of "sequencing" of privatization based on 1992 relative MFP, but the data suggest a higher survival rate for privatized versus state firms and one that is more closely linked to 1992 MFP. The results also imply that MFP gains from privatization are decreasing in pre-privatization MFP. The relatively few cases in which foreign investors take control result in much higher relative MFP, 22-40\% on average, compared to domestic private ownership, but the gap is much lower when the foreign source country is "offshore" an indirect channel for Ukrainian nationals - and it is also lower when the source is Russia. Privatization of $100 \%$ ownership has much larger effects than partial privatization of either minority or majority stakes, ownership structures that have largely disappeared since the early 2000s, as Ukraine has sold off remaining shares. Nevertheless, our database contains more than 1000 majority state-owned manufacturing firms as of 2013 that could be considered for privatization in the future.

JEL Classification: D24, G34, L33, P31

Keywords: productivity, privatization, selection bias, foreign ownership, Ukraine

Corresponding author:

John S. Earle

School of Public Policy

George Mason University

3351 Fairfax Drive, MS 3B1

Arlington, VA 22201

USA

E-mail: earle@gmu.edu

\footnotetext{
* We thank Aleksandr Talavera for helpful comments, Scott Gehlbach and Almos Telegdy for collaboration on related research, and Natalia Akhmina, Tatiana Andreyeva, Serhiy Biletsky, Larisa Leshchenko, Ivan Maryanchyk, Alexander Scherbakov for help with collecting and cleaning the Ukrainian data. Part of the data collection for this research has been supported by grants from the National Council for Eurasian and East European Research and EROC (Economic Research and Outreach Center at the Kyiv School of Economics). All errors are our own.
} 


\section{Introduction}

Privatization is again a priority for the Ukrainian government, with plans for a big push as a part of the general revival of the reform process since the new government and parliament came to power in 2014. It is therefore of more than historical and academic interest to inquire how privatization has proceeded over the 25-odd years of the Ukrainian transition, and what effects it has had on firm performance. In this paper we use panel data on all initially stateowned manufacturing firms to produce evidence on the privatization process and on the evolution of productivity differentials between privatized and state-owned enterprises. Our analysis of the privatization process includes the size of residual state ownership within and across firms, the degree of foreign involvement, and the relative quality of firms privatized early and late in the process. Our estimation of private-state firm-level productivity differentials considers variation associated with domestic versus foreign ownership, percentage privatized, calendar time, privatization year, and region.

The data in our analysis include a remarkably long time series, running from 1989, when Ukraine was still part of the Soviet Union's centrally planned economic system, through 2013, the most recent year available. Not only is this time series longer than in any previous paper on privatization, it also encompasses several turbulent phases in Ukraine's development, such as separation from the Soviet Union, the 1998-1999 financial crisis, and the Orange Revolution. It does not yet include the 2014 "Euromaidan" Revolution and its aftermath, including the ongoing war, although we plan to update our analysis as data become available. However, our analysis of regional variation in productivity differentials provides some initial evidence, which we plan to expand, on the role of differences in the local business environment in conditioning the effects of privatization as well as on differences between Eastern and Western Ukraine that may be important for understanding the current political divisions.

The paper builds on a large previous literature on privatization in many countries as well the small number of previous papers that exist for Ukraine. ${ }^{1}$ In some ways, the paper takes

\footnotetext{
${ }^{1}$ The extensive literature consists primarily of studies of either single countries or small samples from many countries; excellent surveys can be found in Megginson and Netter (2001), Djankov and Murrell (2002), and Estrin et al. (2009). Previous research on privatization and firm performance in Ukraine includes Estrin and Rosevear (1999), who study data from 150 firms in a 1997 survey; Andreyeva (2003) with 1,211 firms observed in 19962000; Akhimova and Schwodiauer (2003) with 202 firms during 1998-2000; and Brown, Earle, and Telegdy (2006) using data similar to those in this paper but running only through 2002. Other related papers on Ukraine include Brown and Earle (2006), Brown, Earle, and Vakhitov (2006), Brown, Earle, and Telegdy (2010), which focus on employment and wage outcomes, Earle and Gehlbach (2015) on productivity and political turnover, and Gorodnichenko and Grygorenko (2008) on oligarch ownership.
} 
Brown, Earle, and Telegdy (2006, henceforth BET) as a starting point in terms of types of data and methods. BET's analysis was also limited to manufacturing firms, but the data ran only through 2002. We nearly double the length of the time series, which allows analysis of the extent of privatization and its effects over a longer window. As we show, a significant number of firms were privatized in the late 1990s, and even after 2000. The longer time series also permits us to examine changes in the relative productivity of privatized firms over time, and the association of these changes with other economic and political changes in the country. In addition, BET was forced to rely on crude indicators of ownership, particularly for foreign investor participation, while this paper uses improved data on shareholdings, especially foreign investors.

The estimation approach in the paper examines the productivity-privatization relationship within industry-year cells to control for aggregate and sector-specific shocks as well as mismeasurement of deflators across industries. The analysis permits differences in estimated production functions across industries to avoid biases associated with technology mismeasurement, and it takes into account selection bias associated not only with fixed differences among firms but also differing trend productivity growth rates. Either of these factors - level and trend differences - may affect the probability of privatization and whether the new owners are domestic or foreign investors. The availability of several years of preprivatization data is also useful for evaluating anticipatory effects and for comparing possible selection bias across specifications. The several years of post-privatization data help shed light on how quickly any benefits from privatization are realized and whether they are sustained or tend to diminish over time.

The paper also examines the heterogeneity of estimated relative productivity effects by event time (centered on privatization year), calendar time, and privatization period (corresponding to dominant method of privatization), and examines possible selection bias in choice of firms for privatization, in sequencing, and in survival. It distinguishes the effects of different types of new private ownership structures - partial privatizations (minority and majority), domestic versus foreign, and the foreign country of origin - whether an "offshore" country (a channel for Ukrainian nationals to hide their ownership), Russia, or other foreign. Finally, it provides estimates separately by oblast, motivated by the long-standing political divides and current civil war in the country. 
Section 2 describes the basic data, while Section 3 describes the ownership measures, evolution of ownership, and privatization policies. Section 4 describes the estimation procedures, and Section 5 presents results. Conclusions are summarized in Section 6.

\section{Data Sources, Variables, and Sample}

The main data source for the firm-level data used to compute productivity is the national statistical office (Derzhkomstat in Ukrainian), which supplies annual industrial enterprise registries for 1989 and 1992-1998 and the enterprise performance statement, balance sheet statement, financial results statement, and the annual foreign direct investment statement for firms in all sectors for 1999-2013. The industrial registries are supposed to include all industrial firms with more than 100 employees plus those that are more than 25 percent owned by the state and/or by legal entities that are themselves included in the registry. In fact, the practice seems to be that once firms enter the registries, they continue to report even if the original conditions for inclusion are no longer satisfied. The data may therefore be taken as corresponding to the "old" sector of firms (and their successors) inherited from the Soviet system. Certainly with respect to this set of firms, the databases are quite comprehensive. At the beginning of the transition process in 1992, the firms in the industrial registry accounted for 94 percent of officially reported total industrial employment. Most of the firms in the sample are tracked from the registry into the other data sets from 1999 onwards, but a small number of new state-owned firms appear throughout (possibly the result of split-ups of previous enterprises), and they are included in the sample as also potentially subject to privatization.

The data contain multiple sources for some of the variables. We use the industrial registry's average capital stock. Capital stock for 1999-2013 comes from the balance sheet statement, where we construct an annual average as the mean of the start-of-year and end-of-year values of tangible assets. In all years we deflate capital stock by removing revaluations; most of these are firm-specific, detected from changes in value of tangible assets from the end of one year to the start of the next, but where there are missing values we substitute industry average changes. Employment and output data for 1999-2013 come from the enterprise performance statement. Employment is defined as the average number of enlisted employees in the year, while output is net sales after indirect taxes. For firm-year observations missing output data in the enterprise performance statement, we use net sales after indirect taxes from the financial results statement. Material costs are unavailable before 1999, so we cannot include them (most 
privatizations occurred before then), but our measurement of multi-factor productivity within industry-year cells accounts for inter-industry variation in material cost usage.

The sample is restricted to manufacturing, which has 22 2-digit industries in the NACE 1.0 classification (Section 'D'). Firms are classified by modal industry, the 2-digit industry they report most often during our period of observation. Only firms that are majority state at first observation are included. Firm-years are retained in the sample only when they contain complete information (nonmissing values for ownership, employment, output, and capital). With these restrictions, the sample consists of 9,221 firms and a total of 117,702 firm-year observations, implying an average of nearly 13 years per firm.

\section{Ownership Data and Privatization Policies}

The main source data for distinguishing private from state ownership is the State Property Fund Registry (SPFR), containing state shares of firm ownership in 1991-2013. For most of the paper, we classify firms as state-owned if the state share in the SPFR is 50 percent or greater. In part of the analysis, we consider the distinction between three types of firms that have undergone some privatization: partially privatized firms with a minority private share, majority-privatized but less than 100 percent private, and 100 percent privatized. For firms first entering the SPFR database with a 100 percent state share, we classify them as state owned in all prior years.

To construct the foreign ownership share, we use information on the non-resident share in the statutory fund reported in the annual foreign direct investment (FDI) statement. The foreign share is not explicitly provided in the FDI statement in 2009-2013, so we calculate it by dividing end-of-year value of nonresident capital by the balance sheet statement's end-of-year value of the statutory fund. Among firms that are majority private, we classify them as foreign private if at least half of the private share is foreign owned, and otherwise they are classified as domestic private.

Firms absent from the SPFR and FDI statements that have a state legal form code are classified as state owned. They are omitted from the analysis of minority privatizations, as we do not know if they have a minority private share or not. After 2007, the legal form code no longer provides a clean distinction between ownership types, and therefore we have consulted the 10percent owner listings in an additional database, Stezha, to clarify subsequent changes of ownership. 
Using the regression sample and dividing private ownership into domestic and foreign, Figure 1 and Table 1 show how ownership shares evolve between 1989 and 2013. Starting from zero, the private share rises rapidly between 1995 and 1998, reaching 69 percent majority private in 1998. The private share gradually increases over the rest of the time period, attaining 68 percent in 2012. The state-owned firm sample remains large enough throughout the period to allow a comparison of their performance to privatized firms. In 2013, the state share is 32 percent. The small increases in state share in some years results from sample changes, not renationalizations. Foreign privatization accounts for a small although steadily increasing share, rising to 5 percent by the end of the period. Foreign firms tend to be relatively large and by 2013 account for 25 percent of manufacturing employment among these initially state-owned companies.

The bottom panel of Table 1 contains numbers of observations in the regression sample, which includes only firms that are majority state at first observation and have complete information (in at least one year) for all variables in the basic regressions. The number of firmyear observations refer to all firm-years for the particular ownership type, while number of firms refers to firms that ever have the ownership type. Of the total sample of 9,221 firms ever appearing in the regression sample, 5,642 become majority private at some point, of which 5,620 become domestic and 322 become foreign. According to our sample rules, all firms had to be state-owned at some point (initially), so the number of firms ever state-owned is the same as the total number of firms in the sample. Firms may also have been domestic private and foreign in different years, so these categories are not mutually exclusive at the firm level.

Because most of our estimation methods rely on ownership changes to identify effects, Table 2 reports the number of switches in the regression sample. The table includes only switches for which the exact year of switch is observed; for some firms missing values create gaps in ownership information. Switches into foreign ownership include a significant number of firms that are initially privatized to domestic owners and later are sold to foreign investors. Because of the small share of foreign-owned firms, we carry out most of the analysis for all privatized firms pooled, but later in the paper we estimate separate effects for foreign versus domestic ownership and also consider variation with the source country of the foreign investment, in particular whether the source is Russia or an "offshore" channel for domestic Ukrainian investors. 
Table 3 and Figure 2 distinguish firms that are completely privatized (100 percent versus majority but less than 100 percent private) and broaden the notion of privatization to include cases of minority privatization. Most privatized firms are 100 percent private throughout the period, except in the single year of 1997 when partially privatized firms account for 33 percent of all firms, 13 and 20 percent for minority and majority, respectively. These cases rapidly disappear, however, as the remaining state shares are privatized. By 2003, 64 percent of all firms are 100 percent privatized while only 5 percent are majority but less than 100 percent, and only 2 percent are minority. Our examination of the productivity consequences of these partial privatizations is perforce confined to the earlier years in the data.

The timing of the ownership variables has a bearing on the interpretation of the estimation results. Ownership is typically measured as of the reporting date, the end of the calendar year. The privatization year is thus defined as the year in which the ownership variable changes from state at the end of $t-1$ to private at the end of $t$. The actual transfer of shares could take place anytime during this year, and the transfer of effective control is even more ambiguous: for instance, it could take place even before the shares are legally conveyed, if it is quite clear who the new owners will be, and it could take place significantly afterwards, if for example it takes time to call a general shareholders' meeting to replace the board and management. These ambiguities imply that the analysis should not be confined to comparisons of the immediate period just before and after the privatization year but instead take a longer perspective on both pre- and post-privatization performance. Our data contain substantial numbers of firms with several observations before and after privatization, facilitating such an analysis.

Ukraine's earliest privatization experiences have some similarities to the "spontaneous" period in Hungary, as the central planning system dissolved at the end of the 1980s and decisionmaking power devolved to managers and work collectives (Frydman et al., 1993b). The provisions for leasing enterprise assets (with eventual buyout) represented the first organized transactions in 1990-1992, but the big impetus for most industrial enterprise privatization was the mass privatization, somewhat similar to Russia's, but at a delayed and slower pace, and the initial design provided even greater advantages to insiders acquiring shares in their companies (Frydman et al., 1993b). At first, privatization resulted in large-scale ownership by managers and workers, some block-holding by domestic entities, and continued state ownership. Subsequently, blocks formed and foreigners made partial inroads. 
This approach to privatization may affect the impact of the policy on firm productivity. Case-by-case sales of large blocks of shares is usually considered the most effective method, and productivity effects of new foreign owners seem likely to be higher than that of domestic investors, as a result of better management skills and access to finance and new technologies, but foreigners may face worse obstacles when layoff decisions are highly politicized and when local networks and knowledge of local conditions are nontransparent. Transfers to employees and mass privatization, the more common methods in Ukraine, face disadvantages. Employees may lack the necessary skills, capital, access to markets, and technologies necessary to turn their firms around, and corporate governance by employees may function particularly poorly when the firm requires difficult restructuring choices involving disparate distributional impacts within the firm. ${ }^{2}$ Mass and voucher privatization programs were intended to increase the speed of privatization by overcoming the problems of insufficient demand due to low domestic savings and reluctance of foreign investors, and if possible to jump-start domestic equity markets with a rapid release of shares. But when combined with strong preferences for employees to use their vouchers in acquiring shares in their employer, as in Ukraine, with highly dispersed ownership structures, the results may be unmonitored managerial control and - according to some unfettered asset-stripping. ${ }^{3}$

The effects of different privatization methods may also manifest themselves differently over time. For example, if concentrated private ownership is necessary to achieve restructuring, then one would expect to see more immediate effects from sales to concentrated outsiders than from voucher or insider privatization, where it takes time for concentrated blocks to form. The subsequent dynamics of the privatization effect may reflect secondary trading leading to increased concentration, however, and firms with high initial levels of inside and dispersed outside ownership may catch up so that the final impact after several years is not very different across ownership types. The paper empirically examines these possibilities below.

\footnotetext{
${ }^{2}$ Frydman and Rapaczynski (1994) and Lipton and Sachs (1990), for instance, argue against privatization to employees, while Ellerman (1993), Stiglitz (1999) and Weitzman (1993) argue in favor. Earle and Estrin (1996) discuss the advantages and disadvantages of worker and manager ownership in the transition setting.

${ }^{3}$ See, e.g., Stiglitz (1999); Black, Kraakman and Tarassova (2000); Kornai (2000); and Roland (2001). Proponents of such programs include Lipton and Sachs (1990), Blanchard et al. (1993), Frydman and Rapaczynski (1994), and Boycko, Shleifer, and Vishny (1994, 1995).
} 


\section{Econometric Framework}

Our basic questions are whether and under what circumstances private versus state ownership matters for firm performance. Early research on the "whether" question examined private and state firms that did not switch ownership type. The estimation therefore relied entirely on cross-sectional variation (e.g., Caves and Christensen 1980). The static comparison in this approach has the obvious drawback that unobserved factors may drive both ownership and performance so that selection bias competes strongly with causality as an interpretation of any observed ownership-performance relationship. Studying privatization (or nationalization) has the advantage of introducing additional identifying information from firm switchers and permitting controls for unobserved factors. Of course, a randomized, controlled trial might overcome the selection bias more convincingly, but we know of no privatization program involving random selection.

Another important estimation issue is defining a control group that provides a baseline for the "treated," privatized firms. Early research using data exclusively on privatized firms lacked "non-treated" comparison firms, and thus had to rely on the changes in performance indicators post-privatization relative to pre-privatization; essentially the pre-privatization period becomes the control group. However, this approach cannot distinguish the measured change from aggregate or firm-specific trends from the same period. In this study, we form a control group from never-privatized SOEs together with the pre-privatization years of subsequently privatized firms. We identify the privatization effect by comparing switchers between state and private ownership with non-switchers.

Comparative equivalency is another estimation issue. Much privatization research analyzes small samples with few observations in each industry. Estimates therefore rely on cross-industry variation, comparing privatized firms in one industry (implicitly, through a regression) with state-owned firms in a different industry. Including industry fixed effects does not address differences in growth or shocks across industries that could correlate with privatization likelihoods. Moreover, available price deflators and exchange rates may not capture price changes and relative price levels perfectly. To remove such effects, our regressions control for a full set of industry-year interactions. Therefore, our estimates represent the difference between privatized firms and controls within the same industry and year. ${ }^{4}$

\footnotetext{
${ }^{4}$ We control for 2-digit industries, of which there are 22. Some industry-year cells are lightly populated, in which case they receive little weight in the regression estimates.
} 
Even within the narrowly-defined cells given by these interactions, selection bias remains possible. Politicians, bureaucrats, managers, employees, and investors may influence whether a firm is privatized. Politicians concerned with unemployment may prefer state ownership for firms with the worst prospects, to protect workers from layoffs and wage cuts. In such cases, employees may oppose privatization. Potential owners would likely prefer firms with better prospects. Our strategy includes firm fixed effects (FE) in the regression to control for any timeinvariant, unobservable factors that affect selection and firm performance. In some specifications, we also add firm-specific trends (a specification we label FE\&FT) to control for differences in performance growth. ${ }^{5}$ We also carry out specification checks to examine evidence on any residual selection bias after these procedures have been applied.

The basic specification for our panel data model, estimated on all firms initially observed as state-owned, takes the following form:

$$
y_{i t}=\mathbf{f}_{\mathbf{j}}\left(k_{i t}, l_{i t}\right)+\mathbf{D}_{\mathbf{j} \mathbf{t}} \gamma_{\mathbf{j t}}+\mathbf{w}_{\mathbf{t}} \boldsymbol{\alpha}_{\mathbf{i}}+\boldsymbol{\theta}_{\mathbf{i t}} \boldsymbol{\delta}+u_{i t},
$$

where $i$ indexes firms from 1 to $N, j$ indexes industries from 1 to $J$, and $t$ indexes time periods (years) from 1989 to 2013. $y_{i t}$ is $\ln$ (output), $\mathbf{f}_{\mathbf{j}}$ is a $1 \mathrm{x} J$ vector of industry-specific Cobb-Douglas production functions, $k_{i t}$ is $\ln$ (capital stock), $l_{i t}$ is $\ln$ (employment), $\mathbf{D}_{\mathbf{j t}}$ is a vector of industry-year interaction dummies, $\gamma_{\mathbf{j t}}$ is the associated vector of coefficients, and $u_{i t}$ is an idiosyncratic error. ${ }^{6}$

The specifications of the other terms in the equation vary across specifications: $\mathbf{w}_{\mathbf{t}}$ is a vector of aggregate time variables, $\boldsymbol{\alpha}_{\mathbf{i}}$ is the vector of associated individual-specific slopes, $\boldsymbol{\theta}_{\mathbf{i t}}$ is the vector of ownership measures, and $\boldsymbol{\delta}$ are the ownership effects of interest in this paper. In the OLS regressions, $\mathbf{w}_{\mathbf{t}} \equiv 0$. In the FE regressions, $\mathbf{w}_{\mathbf{t}} \equiv 1$ such that $\boldsymbol{\alpha}_{\mathbf{i}} \equiv \alpha_{i}$ is the unobserved effect. The FE\&FT model specifies $\mathbf{w}_{\mathbf{t}} \equiv(1, t)$, such that $\boldsymbol{\alpha}_{\mathbf{i}} \equiv\left(\alpha_{1 i}, \alpha_{2 i}\right)$ where $\alpha_{1 i}$ is a fixed unobserved effect and $\alpha_{2 i}$ is the random trend for firm $i$. In practice, the FE\&FT model is estimated in two steps, the first detrending all variables for each firm separately and the second estimating the model on the detrended data.

We investigate several alternative specifications for the ownership variables $\boldsymbol{\theta}_{\text {it }}$. The simplest involves a dummy for private ownership. That is, $\theta_{i t}=1$ during the post-privatization period for privatized firms and $\theta_{i t}=0$ both for the pre-privatization period and for firms always

\footnotetext{
${ }^{55}$ The firm FE also control for the changing nature of the state sector. For instance, if more productive firms are more likely to be privatized then the average productivity in the shrinking state sector would gradually fall, but such differences are removed by the FE if they are time-invariant. If the relative productivity of state sector firms is declining at a steady trend, then these differences are removed by the firm-specific trends.

${ }^{6}$ Brown et al. (2006) report that results are very similar for a wide variety of production function specifications, and also following the suggestion of Syverson (2011), this paper limits attention to a simple Cobb-Douglas specification.
} 
remaining in state ownership. In this case, the parameter of interest, $\boldsymbol{\delta} \equiv \delta_{p}$ represents the mean within-industry-year difference in the dependent variable between privatized firms and majority state-owned firms. ${ }^{7}$ Separate coefficients by ownership type and other cases of heterogeneity come from permitting $\theta_{i t}$ to vary so that $\boldsymbol{\theta}_{\mathbf{i t}}=\theta_{i t} \mathbf{D}_{\mathbf{k}}$ where $\mathbf{D}_{\mathbf{k}}$ is a vector of $\mathbf{k}$ types, and $\boldsymbol{\delta}$ is then a vector of type-specific privatization effects. For example, we distinguish foreign from domestic privatizations with $\boldsymbol{\theta}_{\mathbf{i t}} \equiv\left(\right.$ Domestic $_{i t-1}$, Foreign $\left._{i t-1}\right)$, and $\boldsymbol{\delta} \equiv\left(\delta_{d}, \delta_{f}\right)$, and effects in different time periods with $\boldsymbol{\theta}_{\mathbf{i t}} \equiv\left(\right.$ Private $_{i s}$, Private $\left._{i s}{ }^{\prime}\right)$, where $s$ and $s$ ' refer to different periods of years, and $\boldsymbol{\delta} \equiv$ $\left(\delta_{s}, \delta_{s}\right)$.

We also estimate dynamic specifications, where dummy variables for the years before and after privatization are interacted with indicators for whether the firm is ever domestically privatized or foreign privatized. To avoid small sample problems a long time before or after privatization, we combine in one group all years four and more prior to privatization ("“-4-") and in another all years eight and more afterward (8+). Designating $\tau$ as the index of event time (the number of years since privatization, with the two groups of years on either end) such that $\tau<0$ in the pre-privatization years, $\tau=0$ in the year in which ownership change occurs, and $\tau>0$ in the post-privatization years, we have $\tau=-4-,-3,-2,-1,0,1,2, \ldots, 8+$. Then $\boldsymbol{\theta}_{\mathbf{i t}} \equiv\left(\right.$ Private $\left._{\mathbf{i t} \tau}\right), \boldsymbol{\delta} \equiv$ $\left(\boldsymbol{\delta}_{\tau}\right)$. Our regression specification uses the privatization year $(\tau=0)$ as the reference category.

The motivation for studying these "dynamic" specifications is threefold: First, estimating pre-privatization dynamics provides information on whether firms were already improving productivity prior to the ownership change. Such behavior could be the result of some dynamic selection bias that the model does not account for, and we use the estimated effects of privatization in the period before the privatization year to evaluate the magnitude of this type of selection bias. Second, estimating dynamics just before the privatization year permits an assessment of changes in incentives in anticipation of privatization; such anticipatory effects could be positive if they reflect career concerns of managers hoping either to show new owners their skills or to acquire their companies themselves, or they could be negative if the expectation of post-privatization loss of control - or of job - leads to increased asset-stripping (Aghion, Blanchard, and Burgess, 1994; Roland and Sekkat, 2000). Privatization may be such a disruptive

\footnotetext{
${ }^{7}$ We infer privatization when a firm changes from state to private status between the end of one year and the next. This implies that the date the new owners acquire formal authority (e.g., the first post-privatization shareholders' meeting) varies across firms, with some early in the final pre-privatization year. Some assumption on the first "post" year is necessary in this analysis, but as our estimates of the dynamics of the effect suggest, the results are not at all sensitive to this assumption.
} 
process that any firm suffers a short-run decline in productivity. ${ }^{8}$ Finally, examining postprivatization dynamics is useful for ascertaining the speed with which any estimated effect occurs: is the effect immediate or gradual, becoming significant only with a long lag? Does it tend to be a single jump in productivity, or is it more sustained, with a series of increases over several years? Is it only temporary, as state firms tend to catch up, or does the effect appear to be permanent?

Our method for examining pre-privatization selection bias generalizes the Heckman and Hotz (1989) "pre-program" test for equality of the conditional expectations of the outcome for the treated and control groups in a single pre-treatment period. The identification assumption is that once the test is satisfied, the treatment represents the only cause of differences between the two groups after that period. We carry out $t$ tests of $\tau=-1,-2$, and -3 to address Heckman, LaLonde, and Smith's (1999) concern that if a shock close to the treatment date affects one group but not the other, then the results may be sensitive to the choice of pre-treatment period.

\section{Estimation Results}

Table 4 contains basic estimates for the simplest specification with a dummy for majority private ownership, $\theta_{i t}$, and with the three alternative specifications of the aggregate time variables: $\mathbf{w}_{\mathbf{t}}=0$ for OLS, $\mathbf{w}_{\mathbf{t}} \equiv 1$ such that $\boldsymbol{\alpha}_{\mathbf{i}} \equiv \alpha_{i}$ is the unobserved effect for FE, and $\mathbf{w}_{\mathbf{t}} \equiv(1, t)$, such that $\boldsymbol{\alpha}_{\mathbf{i}} \equiv\left(\alpha_{1 i}, \alpha_{2 i}\right)$ where $\alpha_{1 i}$ is a fixed unobserved effect and $\alpha_{2 i}$ is the random trend for firm $i$ in the FE\&FT specification. In all three cases, the estimated productivity differentials are positive and precisely estimated, but relative to the 0.119 estimated by OLS they are slightly smaller for FE, at 0.102, and still smaller for FE\&FT, at 0.054. Although estimated over a much longer time horizon than BET (2006)'s period that ended in 2002, these results are not very different: BET reported coefficients for Ukraine of 0.161, 0.041, and 0.016 for OLS, FE, and FE\&FT, respectively. But if one puts relatively little weight on the OLS estimates, then our results in this paper do imply larger privatization effects than BET inferred from their estimates. Shortly, we shall investigate the extent to which the larger estimates we report now are reflecting larger productivity differentials arising in the last dozen years or so of the period, and we shall put the results in context by comparing these results to BET's estimates for other countries.

\footnotetext{
${ }^{8}$ The dynamics just before the privatization year may show effects analogous to "Ashenfelter's dip" in training evaluations - where workers about to enroll in a training program experience a drop in earnings.
} 
First, however, in order to have a better understanding of the different estimation methods, as well as to assess the short-run versus long-run productivity differentials, Table 5 contains results for the event-time model described above, with the coefficients plot in Figure 3. For the pre-privatization period, the estimated coefficients are mostly very small and statistically insignificant, and they show no sign of a trend. The one exception is the OLS coefficient for the pre-privatization year $\tau=-1$, which is positive and statistically significant. Both the FE and the FE\&FT specifications thus pass the pre-program test for $\tau=-1,-2$, and -3 , implying they show no evidence of either selection bias or anticipatory behavior (restructuring or asset-stripping) prior to privatization. Indeed, the results also show no effects in the first post-privatization year $\tau$ $=1$. Of course, these conclusions are limited to productivity, and they do not control for all possible types of selection bias. To interpret the post-privatization estimates of Tables 4 and 5 as causal requires an additional identifying assumption that there is no post-privatization shock to productivity that is coincident with but not the result of privatization. It would represent a particular threat to identification if such a shock were anticipated by the future private owners and therefore motivated their acquisition. We find this possibility somewhat implausible, but we cannot rule it out, and it should be borne in mind as a caveat to causal interpretation of our estimates.

Turning to the estimates in Table 5 and Figure 3 for the post-privatization years, the coefficients are essentially zero in all three specifications for the first post-privatization year, as already noted, and only in $\tau=2$ do we observe a positive jump in the FE and FE\&FT specifications of about 0.04 , followed by accelerating increases for several years, and then smaller increases after about 5-6 years. The OLS specification shows a productivity differential emerging more slowly but ultimately growing slightly more than in the FE\&FT, although less than under FE. If we take the FE and FE\&FT specifications as preferred, then the results imply a relative productivity gap of 15-17 percent opens up between privatized and state-owned firms by five years after privatization.

We next consider whether the post-2002 calendar period differs from the preceding period through 2002 (2002 was the last year covered by BET), by permitting the privatization coefficient to vary over these two periods. Results are presented in Table 6. Both FE and FE\&FT show much larger productivity differentials post-2002.

How do these results compare with similar findings for other countries? The most comparable study, in terms of types of data and methods, is BET (2006), results from which are 
shown in Figure 4. The first four sets of two bars each display BET's published FE and FE\&FT estimates for Hungary, Romania, Russia, and Ukraine, respectively (BET, Table 5, P. 80). The last two sets of bars contain the results from Table 6. The results for Ukraine in the fifth group, referring to the same period BET study through 2002, confirm BET's conclusion that the productivity effect of privatization in Ukraine was substantially lower than in Hungary and Romania, but larger than in Russia. But the small upward revision in the point estimates (from 2-4 percent in BET to 5 percent in our estimates from Table 6), coupled with the similar size of standard errors here and in BET, makes these coefficients statistically significantly different from zero at the 1 percent level, while for BET they were statistically insignificant.

However, the difference in the post-2002 period is much more dramatic, with higher estimates by both FE and FE\&FT than BET obtained for Hungary and Romania. Of course, relative productivity of privatized versus state-owned firms in Central Europe may also have evolved since BET's analysis of the period through 2002, so the comparison may not be entirely fair, but it does seem reasonable to conclude that the relative productivity in Ukraine in recent years has reached and even exceeded that shown by the Central European countries earlier on. The widening productivity differential of privatized relative to state firms in Ukraine is a central finding that we explore in various ways through much of the rest of this paper.

The widening productivity differential might result from lags in restructuring that take time to be realized in higher productivity, or they might result from better quality firms being privatized or better quality privatization methods in the more recent years. As discussed in Section 3, the dominant method in the mid-1990s was mass privatization using vouchers and giveaways to managers and workers, resulting in dispersed insider ownership, while most privatization since 1997 has involved sales of shares to outside investors, resulting in more outside concentrated block-holdings. Unfortunately, our data contain no firm-level information on the privatization methods employed in particular cases, but the method is highly correlated with timing. To make some progress in assessing the role of method, we therefore permit the coefficients to vary according to whether the privatization year is post-1997 or through-1997, with results shown in Table 7. The results imply a much higher impact of privatization through 1997 compared to afterward, when it is close to zero and statistically insignificant in both the FE and FE\&FT specifications. The results thus appear to be inconsistent with conventional expectations on the greater efficacy of concentrated versus dispersed ownership and on outsiders versus insiders. But we caution that our evidence here is highly indirect and does not account, 
for example, for cases of mixed ownership. Moreover, the early privatizations have had more time for concentration to develop as well as for restructuring and productivity-improving activities.

A related question posed in some research on privatization is whether there is systematic selection in the sequencing of firms for privatization according to firm quality. For instance, Gupta et al. (2008) report that better firms tend to be privatized earlier in the Czech Republic. We take a step towards assessing this possibility in Ukraine by estimating differentials in productivity in 1992 of firms to be privatized in the future relative to firms that were never privatized, where we permit the differential to vary by whether privatization occurred in years up to 1997, or if it occurred from 1998 onward. The coefficients (standard errors) for the earlier and later period are $0.235(0.024)$ and $0.277(0.032)$. These results imply no large differences in the average quality of firms privatized in the two periods, but if anything they show a rising relative productivity, implying that at least in this sense, sequencing of privatization was reversed: better quality firms were privatized later, after the mass privatization finished. Of course, this simple form of selection bias in pre-privatization level of productivity is controlled for with firm FE (just as selection bias in trend productivity is controlled with FT).

Another potential bias could arise from differential patterns of survival among privatized and state-owned firms. The counterpart to gradual privatization is the shrinking of the state sector, and exit may occur from both sectors at different rates and with different productivity levels, possibly affecting the privatized-state comparison. To study this over the entire transition period in our data, we estimate survival through 2013 for all firms in 1992 as a function of whether or not they are privatized and of their MFP in 1992. MFP is computed as the 1992 residuals from a production function as in Equation (1) - but with no ownership variables, of course. The inclusion of industry-year interactions implies that MFP is measured relative to the industry mean in 1992, and we also include industry dummies in the probit to control for differential exit rates by industry. The estimates of the marginal effects in Table 8 imply a much higher survival rate for privatized firms as the coefficient of 0.256 compared to a mean survival rate in the whole sample of 0.4. The relative MFP interactions imply a stronger sensitivity of exit behavior among privatized compared to state firms in the sense that the probability of survival is estimated to increase more with relative MFP.

While these results suggest that the composition of the residual state sector in Ukraine has indeed been changing relative to the privatized sector, note that the inclusion of firm FE and 
FT in our estimating equation controls for the most obvious types of survival bias. Firm FE remove any time-invariant differences and firm FT remove any constant trending differences between state and private firms; if the state sector post-2002 for instance has firms with below average pre-2002 productivity, the FE would control for this difference, or if the state sector increasingly consists of firms with negative productivity trends, the FT would control for this. Our result of an increasing productivity gap between privatized and state firms suggests instead an accelerating improvement in privatized relative to state, or an accelerating deterioration in state firms relate to private; indeed these alternatives cannot be distinguished without imposing stronger assumptions because our analysis rests precisely on the relative productivity of these two groups.

Another question raised by this analysis, one that may have implications for current policy decisions, is whether the estimated impact of privatization is larger or smaller depending on the firm's pre-privatization quality. Here we measure quality as relative MFP in the year prior to privatization, again using the firm-year residuals from a production function as in Equation (1), except for the absence of ownership variables and firm fixed effects and trends (since these are intended to control for bias in the ownership estimates), and include an interaction of this relative MFP measure with privatization. The results, shown in Table 9, imply that the privatization impact decreases in pre-privatization productivity. In a quadratic specification, not shown here, the relationship is concave, suggesting that privatization is most effective for below-average productivity firms and loses its effectiveness for firms at double the mean productivity. This suggests that a residual state sector of low average productivity might benefit from privatization.

Turning to differences in ownership structure, we first consider variation with percentage privatized, which is a relatively under-studied question in the privatization literature. Table 3 showed that there were substantial numbers of partial privatizations in the mid to late 1990s, both minority and majority (but less than 100 percent), although they largely disappeared in the early 2000s. Because of this disappearance, we estimate effects only for the earlier period through 2002, distinguishing 100 percent private from majority from less than 100 percent, and 100 percent state from minority private. The results in Table 10 show that only the 100 percent privatizations during this period are associated with positive productivity differentials, of 6-7 percent for both FE and FE\&FT. Majority but less than 100 percent privatizations are estimated to have small negative differentials during this period, while minority privatizations are 
associated with larger negative differentials, suggesting partial privatization may have worsened firm performance in these cases and years, possibly creating costly fights for control and separating ownership and control, leading to asset-stripping. It bears emphasis that these results pertain to the immediate post-privatization phase in the mid to late 1990s, and subsequently, as shown in Table 3, the partially privatized firms eventually became 100 percent privatized. This process may be a major factor behind the increase relative productivity of privatized firms in the second compared to the first decade of transition.

Another important dimension of private ownership type is foreign versus domestic. Results from permitting the coefficient to vary across these two types are shown in Panel A of Table 11. In all cases, the estimated foreign coefficient is 3-4 times larger than the domestic (the latter are very similar to the overall privatization coefficients because of the very small share of foreign privatizations). The much larger estimated effect of foreign ownership after privatization is consistent with BET (2006) and other studies for other countries.

A much less studied question, which our data on Ukraine permit us to pursue, is whether the source country of foreign investment matters. In the case of Ukraine, and other transition and emerging economies, a particularly interesting case is that of the so-called "offshore" countries, locations through which domestic actors may channel ownership in order to avoid taxes and hide ownership. In Ukraine's case, there have been official lists of such countries since 2000, and the list was updated as recently as May 2015. ${ }^{9}$ The importance of the issue is also highlighted by official statistics on foreign direct investment, which shows Cyprus as the largest source country. This is also true in our data. Naturally, the suspicion arises that if these putatively foreign investments are in fact disguised domestic, then the associated relative productivities may be closer to domestic. We do not observe the true owners, but our data do contain information on source country. In addition to distinguishing the offshores, we also separate out Russia, which is of special interest in the current political situation. Our data contain 77 privatized firms with Russian ownership, as well as 156 from offshore countries.

Results from distinguishing these three types of "foreign" ownership - offshore countries, Russia, and other countries - are shown in Table 11, Panel B. The coefficient on offshore source country is much lower than that of other countries; in the FE specification it is only about a third

\footnotetext{
${ }^{9}$ See Cabinet of Ministers 2015b. The list includes more than 73 countries, of which Lichtenstein, Switzerland, Moldova, Panama, OAE, Ireland, Cyprus, British Virgin Islands, Virgin Islands, Belize, Bermuda, Bahamas, Seychelles, Saint Kitts, and Nevis are represented in our data.
} 
(0.215 versus 0.605$)$ while for the FE\&FT it is only about a fifth ( 0.070 versus 0.352$)$, and in the latter case it is scarcely higher than domestic privatization and is statistically insignificantly different from zero. The coefficient on Russian ownership is higher than for offshores but it is also much lower than for "other foreign:" in the FE\&FT it is only about half (0.194 versus 0.352). Evidently, not all foreign investors are alike in their ability to raise productivity in privatized companies.

A related issue is regional variation in the productivity differential associated with privatization. In the current political situation, it could be of interest if privatization was relatively successful in some regions and less so in others. For instance, opposition to reforms in Eastern Ukraine might be fueled by unsuccessful privatization in addition to, or instead of, the ethnic conflict that usually receives attention. Brown, Earle, and Gehlbach (2009, 2013) find significant variation in the privatization effect across Russian regions, and in the 2000s the effect becomes most positive in Western regions surrounding and including Moscow. To investigate whether something similar has occurred in Ukraine, Figure 5 shows results from regressions interacting the majority private dummy with the 27 Ukrainian regions (oblasts) for FE and FE\&FT. The estimating equation includes a set of interactions between privatization and demeaned industry dummies to control for possible compositional differences across regions. As in Russia, the estimated privatization effect varies widely across regions. Though there is some change in regional rankings across methods, Chernihiv, Crimea, Dnipropetrovsk, Kyiv, Kyiv Oblast, Odessa, Sevastopol, and Volyn stand out as having more effective privatization than average, and Ivano-Frankivsk, Luhansk, Mykolayiv, Poltava, Rivne, Ternopil, and Zhytomir are

consistent underperformers. The effect does not vary systematically from East to West or by distance to Kyiv. One factor that distinguishes some of the better performers is transport links to Western markets (e.g., Crimea, Odessa, and Sevastopol are Black Sea ports and Kyiv has an international airport). Explaining the regional variation could be a useful task for future research.

\section{Conclusion}

Following the Euromaidan events in Ukraine, a new Parliament was elected in October 2014, and a new coalition of parties was formed on the basis of a Coalition Agreement that included "reform of state property and privatization" as a major policy of the new government. The details of the Agreement provide for 1) reducing the list of state property not permitted to be 
privatized, 2) mandatory corporatization of all state firms, and 3) sale of investment-attractive assets and preparation for privatization according to the best international practices, among others. In May, while we were revising this paper, the Cabinet of Ministers approved a list of more than 300 state companies to be privatized this year (Cabinet of Ministers, 2015a).

The results in this paper provide some support for this policy and some analysis that may be useful to policymakers as they develop the details of the privatization programs. To start with, we find evidence of a strong contribution of privatization to aggregate manufacturing productivity growth in Ukraine during the transition period. While the possibility of selection bias in estimating the effects of privatization is an important concern in privatization studies, this paper has exploited unusually extensive data comprehensively covering manufacturing firms for a long period of time before and after privatization as well as include the state-owned comparison group. The paper employs panel data techniques that are commonly used in the evaluation of labor market programs and that permit evaluations of some important forms of potential selection bias.

The estimation results imply a substantial positive effect of privatization on productivity. While results differ in some details across specifications, they are remarkably consistent, implying a 5-10 percentage point higher productivity in privatized firms on average that results from a steadily widening gap. We estimate that by 5 years after privatization, the productivity gap has widened to 15-17 percent, in our preferred specifications. The effect also increases in calendar time: while we essentially replicate the findings in BET (2006) that through 2002 Ukrainian privatization raises productivity no more than 5 percent, placing Ukrainian results well below Hungary and Romania although above Russia for the early transition period, with our new data after 2002 we find estimated average effects of 16-27 percent. These estimates compare favorably with those from the Central European countries in the earlier period.

To understand this central finding more deeply, we also analyze privatization cohorts, finding that earlier cohorts actually out-perform later privatizations in terms of the productivity differentials generated, despite the generally higher quality of the privatization methods (sales leading to concentrated outside blockholdings) of the later privatizations. We find much higher survival rates among privatized firms, and also a much stronger link to pre-reform productivity, suggesting that privatization has aided the process of productivity-enhancing reallocation. Somewhat surprisingly to some observers, we find that privatization tends to raise productivity the most at firms with lower pre-privatization productivity, possibly because those with high 
productivity are already close to the frontier.

Examining different types of ownership structures, we provide results on partial privatizations for the early period when they were more prevalent than recently when they have largely disappeared. We find negative impacts of both types of partial privatization, especially for minority privatization, possibly because of conflicts among a variety of owners lacking clear control and the attendant incentives to strip assets rather than restructure.

Our results for foreign ownership confirm previous research in showing much larger productivity effects compared to domestic private ownership, but we also divide foreign investors by source country, including "offshore" countries (which may conceal ownership of Ukrainian nationals), Russia, and all other countries as separate categories. Such data are fairly unusual, but they permit us to show that "foreign" ownership from offshore countries has a much smaller productivity impact than from non-offshore countries, scarcely different from that of domestic investors, in the specification with firm fixed effects and trends. Ownership from Russia is associated with lower productivity impacts than other countries, but higher than offshore. The offshore results suggest both that the true level of foreign participation is lower than the official classification makes it appear and that the true impact of foreign participation on productivity is even much higher.

Finally, we find systematic differences in the estimated impact of privatization across Ukrainian regions, but these differences are not correlated with east/west or north/south axes. They do seem to be related to access to markets through transportation hubs.

Many questions and criticisms were raised about the nature of the privatization policies in Ukraine, especially in the early to mid-1990s before there was any significant foreign investment or sales to outside block-holders. The immediate results of these initial policies were dispersed ownership structures dominated by insiders (both managers and workers), and few observers expected that well-functioning corporate governance leading to productive restructuring would be the consequence. Indeed, the results in this paper suggest that improved productivity in privatized firms did emerge more slowly than in some well-documented Central European cases, such as Hungary and Romania (Brown et al., 2006). Although it cannot be demonstrated from available data, the insider-owners may have been slow to learn about effective ways to restructure, and ownership concentration may have taken time to develop. Yet what is clear from the data is that the privatized firms in Ukraine have steadily widened their productivity gap vis-a-vis state-owned enterprises, so that after several years the productivity effect of 
privatization in Ukraine is actually quite similar to those of its Central European counterparts. These results provide further, updated evidence of the value of privatization in enhancing productivity in this particular economy. 


\section{References}

Aghion, Philippe, Olivier Blanchard, and Robin Burgess, "The Behavior of Firms in Eastern Europe, Pre-Privatization.” European Economic Review, Vol. 38: 1327-1349, 1994.

Akhimova, Iryna, and Gerhard Schwodiauer, "Ownership Structure, Corporate Governance and Enterprise Performance: Empirical Results for Ukraine.” Institute for Economic Research and Policy Consulting Working Paper No. 21, 2003.

Andreyeva, Tatiana, “Company Performance in Ukraine: What Governs its Success." Economics Education and Research Consortium Working Paper No. 03/01, 2003.

Ashenfelter, Orley, and David Card, "Using the Longitudinal Structure of Earnings to Estimate the Effect of Training Programs." Review of Economics and Statistics, Vol. 67(4), 648-660, November 1985.

Arellano, Manuel, "Computing Robust Standard Errors for Within-Groups Estimators." Oxford Bulletin of Economics and Statistics, Vol. 49(4), 431-434, November 1987.

Black, Bernard, Reiner Kraakman, and Anna Tarassova, "Russian Privatization and Corporate Governance: What Went Wrong?” Stanford Law Review, Vol. 52(6): 1731-1808, July 2000.

Blanchard, Olivier, Maxim Boycko, Marek Dabrowski, Rudiger Dornbusch, Richard Layard, and Andrei Shleifer, Post-Communist Reform: Pain and Progress. Cambridge, MA: MIT Press, 1993.

Boycko, Maxim, Andrei Shleifer, and Robert W. Vishny, "Voucher Privatization." Journal of Financial Economics, Vol. 35(2): 249-266, April 1994.

Boycko, Maxim, Andrei Shleifer, and Robert W. Vishny, Privatizing Russia. Cambridge, MA: MIT Press, 1995.

Brown, J. David, and John S. Earle, "Job Reallocation and Productivity Growth in the Ukrainian Transition." Comparative Economic Studies, Vol. 48(2), 229-251, June 2006.

Brown, J. David, John S. Earle, and Scott Gehlbach, "Helping Hand or Grabbing Hand? State Bureaucracy and Privatization Effectiveness." American Political Science Review Vol. 103: 264-283, 2009.

Brown, J. David, John S. Earle, and Scott Gehlbach, "Privatization." In Michael Alexeev and Shlomo Weber, eds: The Oxford Handbook of the Russian Economy. Oxford, New York: Oxford University Press, 2013.

Brown, J. David, John S. Earle, and Álmos Telegdy, "The Productivity Effects of Privatization: Longitudinal Estimates from Hungary, Romania, Russia, and Ukraine." Journal of Political Economy, Vol.114(1), 61-99, February 2006.

Brown, J. David, John S. Earle, and Álmos Telegdy, "Employment and Wage Effects of Privatisation: Evidence from Hungary, Romania, Russia, and Ukraine." Economic Journal, Vol. 120, 683-708, 2010.

Brown, J. David, John S. Earle, and Volodymyr Vakhitov, "Wages, Layoffs, and Privatization: Evidence from Ukraine.” Journal of Comparative Economics, Vol. 34(2), 272-294, June 2006.

Cabinet of Ministers, Government of Ukraine, Resolution No. 271, "One Transparent and Competitive Privatization in 2015," May 2015a. Accessed at: http://www.kmu.gov.ua/control/uk/cardnpd?docid=248152310. 
Cabinet of Ministers, Government of Ukraine, Regulation No. 449-p "On approving the list of countries (territories) that meet the criteria established in subsection 39.2.1.2 subparagraph 39.2.1 paragraph 39.2 of Article 39 of the Tax Code of Ukraine," May 14, 2015b.

Caves, Douglas W., and Laurits R. Christensen, "The Relative Efficiency of Public and Private Firms in a Competitive Environment: The Case of Canadian Railroads." Journal of Political Economy, Vol. 88, 958-976, 1980.

Djankov, Simeon, and Peter Murrell, "Enterprise Restructuring in Transition: A Quantitative Survey." Journal of Economic Literature, Vol. XL(3), 739-792, September 2002.

Earle, John S., and Saul Estrin, "Employee Ownership in Transition." In Roman Frydman, Cheryl W. Gray, and Andrzej Rapaczynski, eds., Corporate Governance in Central Europe and Russia. Insiders and the State, pp. 1-61. Budapest: World Bank and CEU Press, 1996.

Earle, John S., and Saul Estrin, "After Voucher Privatization: The Structure of Corporate Ownership in Russian Manufacturing Industry." Discussion Paper No. 1736. London: CEPR, December 1997.

Earle, John S., and Scott G. Gehlbach, "The Productivity Consequences of Political Turnover: Firm-Level Evidence from Ukraine's Orange Revolution.” American Journal of Political Science, Vol. 59(3), 708-723, 2015.

Earle, John S., Csaba Kucsera, and Álmos Telegdy, "Ownership Concentration and Corporate Performance on the Budapest Stock Exchange: Do Too Many Cooks Spoil the Goulash?" Corporate Governance, Vol. 13(2), 254-264, March 2005.

Earle, John S., and Álmos Telegdy, "Privatization Methods and Productivity Effects in Romanian Industrial Enterprises." Journal of Comparative Economics, Vol. 30: 657-682, 2002.

Ellerman, David, "Management and Employee Buy-Outs in Central and Eastern Europe: Introduction." In David Ellerman, ed., Management and Employee Buy-Outs as a Technique of Privatization, pp. 13-30. Ljubljana: Central and Eastern European Privatization Network, 1993.

Estrin, Saul, Jan Hanousek, Evzen Kocenda, and Jan Svejnar, "The Effects of Privatization and Ownership in Transition Economies." Journal of Economic Literature, Vol. 47: 699-728, 2009.European Bank for Reconstruction and Development (EBRD), Transition Report. London: EBRD, 2000.

Estrin, Saul and Adam Rosevear, "Enterprise performance and corporate governance in Ukraine.” Journal of Comparative Economics, Vol. 27 (3), 442-458, 1999.

Frydman, Roman, Cheryl W. Gray, Marek Hessel, and Andrzej Rapaczynski, "When Does Privatization Work? The Impact of Private Ownership on Corporate Performance in the Transition Economies." Quarterly Journal of Economics, Vol. 114(4): 1153-1192, November 1999.

Frydman, Roman, and Andrzej Rapaczynski, Privatization in Eastern Europe: Is the State Withering Away? Budapest: Central European University Press, 1994.

Frydman, Roman, Andrzej Rapaczynski, John S. Earle, et al., The Privatization Process in Central Europe. London: CEU Press, 1993a.

Frydman, Roman, Andrzej Rapaczynski, John S. Earle, et al., The Privatization Process in Russia, Ukraine, and the Baltic States. London: CEU Press, 1993b.

Gorodnichenko, Yuriy, and Yegor Grygorenko, "Are Oligarchs Productive? Theory and Evidence." Journal of Comparative Economics, Vol. 36(1), 17-42 March 2008. 
Gupta, Nandini, John C. Ham, and Jan Svejnar, "Priorities and Sequencing in Privatization: Theory and Evidence from the Czech Republic." European Economic Review, Vol. 52: 183-208, 2008.

Heckman, James J., and V. Joseph Hotz, "Choosing Among Alternative Nonexperimental Methods for Estimating the Impact of Social Programs: The Case of Manpower Training." Journal of the American Statistical Association, Vol. 84(408), 862-874, December 1989.

Heckman, James J., Robert J. LaLonde, and Jeffrey Smith, "The Economics and Econometrics of Active Labor Market Programs." In Orley Ashenfelter and David Card, eds., Handbook of Labor Economics, Volume 3A. Elsevier: Amsterdam, 1999.

Jacobson, Louis S., Robert J. LaLonde, and Daniel G. Sullivan, "Earnings Losses of Displaced Workers." American Economic Review, Vol. 83(4), 685-709, September 1993.

Jacobson, Louis S., Robert J. LaLonde, and Daniel G. Sullivan, "Estimating the Returns to Community College Schooling for Displaced Workers." Journal of Econometrics, Vol. 125, 271-304, 2005.

Kézdi, Gabor, "Robust Standard Error Estimation in Fixed-Effects Panel Models." Mimeo, University of Michigan Department of Economics, October 13, 2003.

Kornai, Janos, “Ten Years after 'The Road to a Free Economy': The Author's Self-Evaluation." Economic Systems, Vol. 24(4): 353-359, December 2000.

Lipton, David, and Jeffrey D. Sachs, "Privatization in Eastern Europe: The Case of Poland." Brookings Papers on Economic Activity 0/2: 293-333, 1990.

Megginson, William L., and Jeffry M. Netter, "From State to Market: A Survey of Empirical Studies on Privatization.” Journal of Economic Literature, Vol. 39(2): 321-389, June 2001.

Roland, Gerard, "Corporate Governance and Transition Economies: Lessons from Transition." In Boris Pleskovic and Nicholas Stern, eds., Annual World Bank Conference on Development Economics 2000, pp. 331-352. Washington, D.C.: World Bank, 2001.

Roland, Gerard, and Khalid Sekkat, "Managerial Career Concerns, Privatization and Restructuring in Transition Economies." European Economic Review, Vol. 44: 1857-1872, 2000.

Stiglitz, Joseph, "Whither Reform? Ten Years of the Transition." http://www.worldbank.org/ research/abcde/washington_11/stiglitz.html. Washington, D.C.: World Bank, 1999.

Voszka, Eva, "Spontaneous Privatization in Hungary." In John S. Earle, Roman Frydman, and Andrzej Rapaczynski, eds., Privatization in the Transition to a Market Economy: Studies of Preconditions and Policies in Eastern Europe, pp. 89-107. London: Pinter Publishers, and New York: St. Martin's Press, 1993.

Weitzman, Martin, "How Not to Privatize." In Mario Baldassarri, Luigi Paganetto, and Edmund Phelps, eds., Privatization Processes in Eastern Europe, pp. 249-269. New York: St. Martin's Press, 1993.

Wooldridge, Jeffrey, "Fixed-Effects and Related Estimators for Correlated Random-Coefficient and Treatment-Effect Panel Data Models." Review of Economics and Statistics, Vol. 87(2), 385390, May 2005.

World Bank, From Plan to Market: World Development Report 1996. Oxford: Oxford University Press, 1996. 
Table 1: Share of Privatized (Domestic and Foreign) and State-Owned Firms by Year, 1989-2013

\begin{tabular}{|c|c|c|c|c|c|}
\hline Year & Privatized & Domestic & Foreign & State & $\mathrm{N}$ \\
\hline 1989 & 0.00 & 0.00 & 0.00 & 1.00 & 3,947 \\
\hline 1992 & 0.00 & 0.00 & 0.00 & 1.00 & 6,591 \\
\hline 1993 & 0.00 & 0.00 & 0.00 & 0.99 & 6,669 \\
\hline 1994 & 0.08 & 0.08 & 0.00 & 0.92 & 5,508 \\
\hline 1995 & 0.18 & 0.18 & 0.00 & 0.82 & 5,564 \\
\hline 1996 & 0.31 & 0.31 & 0.00 & 0.69 & 4,999 \\
\hline 1997 & 0.50 & 0.50 & 0.00 & 0.50 & 4,972 \\
\hline 1998 & 0.68 & 0.67 & 0.01 & 0.32 & 5,797 \\
\hline 1999 & 0.67 & 0.66 & 0.01 & 0.33 & 6,724 \\
\hline 2000 & 0.69 & 0.68 & 0.01 & 0.31 & 6,302 \\
\hline 2001 & 0.68 & 0.67 & 0.01 & 0.32 & 6,299 \\
\hline 2002 & 0.68 & 0.67 & 0.01 & 0.32 & 6,077 \\
\hline 2003 & 0.69 & 0.67 & 0.02 & 0.31 & 5,802 \\
\hline 2004 & 0.68 & 0.65 & 0.02 & 0.32 & 5,476 \\
\hline 2005 & 0.67 & 0.64 & 0.03 & 0.33 & 5,226 \\
\hline 2006 & 0.68 & 0.66 & 0.03 & 0.32 & 4,803 \\
\hline 2007 & 0.68 & 0.65 & 0.03 & 0.32 & 4,606 \\
\hline 2008 & 0.68 & 0.64 & 0.04 & 0.32 & 4,286 \\
\hline 2009 & 0.68 & 0.64 & 0.04 & 0.32 & 4,078 \\
\hline 2010 & 0.67 & 0.63 & 0.04 & 0.33 & 3,751 \\
\hline 2011 & 0.67 & 0.63 & 0.04 & 0.33 & 3,597 \\
\hline 2012 & 0.68 & 0.64 & 0.05 & 0.32 & 3,391 \\
\hline 2013 & 0.68 & 0.64 & 0.05 & 0.32 & 3,237 \\
\hline $\begin{array}{l}\text { No. of } \\
\text { Firm-years }\end{array}$ & 59,534 & 57,651 & 1,883 & 58,168 & 117,702 \\
\hline $\begin{array}{l}\text { No. of } \\
\text { Firms }\end{array}$ & 5,642 & 5,620 & 322 & 9,221 & 9,221 \\
\hline
\end{tabular}

Note: Ownership is measured as of beginning of the year; see text for definitions. No. of firm-years refer to all observations on a particular ownership-type; no. of firms refer to cases that ever have the particular ownership-type. Some firms are domestic private in some years and foreign in others. All firms are initially state-owned. 
Figure 1: Share of Privatized (Domestic and Foreign) and StateOwned Firms by Year, 1989-2013

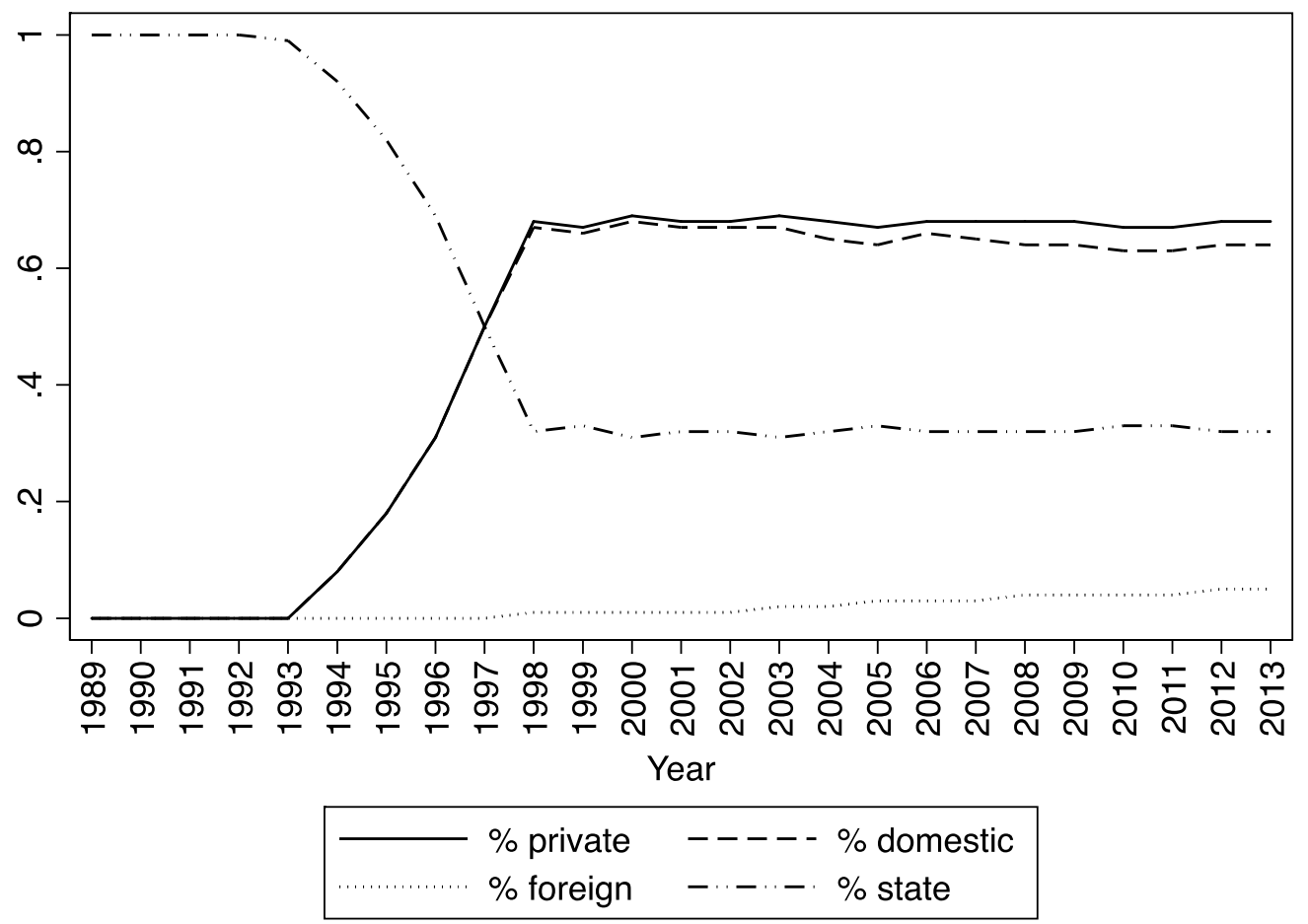

Note: This is a time plot of the contents of Table 1. 
Table 2: Number of Ownership Switches

\begin{tabular}{rrrr}
\hline Year & Privatized & Domestic & Foreign \\
\hline 1989 & 0 & 0 & 0 \\
1992 & 0 & 0 & 0 \\
1993 & 450 & 450 & 0 \\
1994 & 532 & 532 & 0 \\
1995 & 576 & 576 & 0 \\
1996 & 950 & 950 & 0 \\
1997 & 533 & 528 & 39 \\
1998 & 396 & 395 & 20 \\
1999 & 152 & 165 & 6 \\
2000 & 80 & 83 & 10 \\
2001 & 44 & 55 & 16 \\
2002 & 112 & 111 & 33 \\
2003 & 39 & 42 & 26 \\
2004 & 34 & 38 & 21 \\
2005 & 20 & 38 & 15 \\
2006 & 9 & 15 & 15 \\
2007 & 9 & 20 & 38 \\
2008 & 4 & 10 & 15 \\
2009 & 0 & 5 & 22 \\
2010 & 1 & 10 & 11 \\
2011 & 1 & 12 & 9 \\
2012 & 1 & 7 & 6 \\
2013 & 0 & 3 & 28 \\
\hline Total & 3,943 & 4,045 & 330 \\
\hline
\end{tabular}

Note: Switches are categorized by the ownership type switched into. Firms may switch into (and between) domestic private and foreign multiple times. Firms for which the switch year is unknown are excluded. 
Table 3: Evolution of Ownership Types by Percent Private

\begin{tabular}{lcccc}
\hline Year & $\begin{array}{c}100 \% \\
\text { Private }\end{array}$ & $\begin{array}{c}\text { Majority } \\
\text { Private }\end{array}$ & $\begin{array}{c}\text { Minority } \\
\text { Private }\end{array}$ & $\begin{array}{c}\text { State and } \\
\text { Other }\end{array}$ \\
\hline 1992 & 0.00 & 0.00 & 0.00 & 1.00 \\
1993 & 0.00 & 0.00 & 0.00 & 1.00 \\
1994 & 0.08 & 0.01 & 0.01 & 0.90 \\
1995 & 0.15 & 0.03 & 0.04 & 0.78 \\
1996 & 0.23 & 0.09 & 0.11 & 0.57 \\
1997 & 0.30 & 0.20 & 0.13 & 0.37 \\
1998 & 0.49 & 0.19 & 0.09 & 0.23 \\
1999 & 0.51 & 0.16 & 0.06 & 0.27 \\
2000 & 0.56 & 0.13 & 0.04 & 0.27 \\
2001 & 0.58 & 0.10 & 0.04 & 0.28 \\
2002 & 0.60 & 0.08 & 0.03 & 0.29 \\
2003 & 0.64 & 0.05 & 0.02 & 0.29 \\
2004 & 0.64 & 0.04 & 0.02 & 0.30 \\
2005 & 0.64 & 0.03 & 0.02 & 0.31 \\
2006 & 0.66 & 0.02 & 0.02 & 0.30 \\
2007 & 0.66 & 0.02 & 0.02 & 0.30 \\
2008 & 0.66 & 0.01 & 0.02 & 0.31 \\
2009 & 0.67 & 0.01 & 0.01 & 0.31 \\
2010 & 0.66 & 0.01 & 0.01 & 0.32 \\
2011 & 0.66 & 0.01 & 0.01 & 0.32 \\
2012 & 0.67 & 0.01 & 0.01 & 0.31 \\
2013 & 0.67 & 0.01 & 0.01 & 0.31 \\
\hline
\end{tabular}

Notes: The "majority private" category excludes 100 percent private. The "state and other category" includes 100 percent state-owned firms and firms classified as state by property form for which the exact state share is unknown (but likely to be 100 percent and almost certainly a majority). 
Figure 2: Evolution of Ownership Types by Percent Private

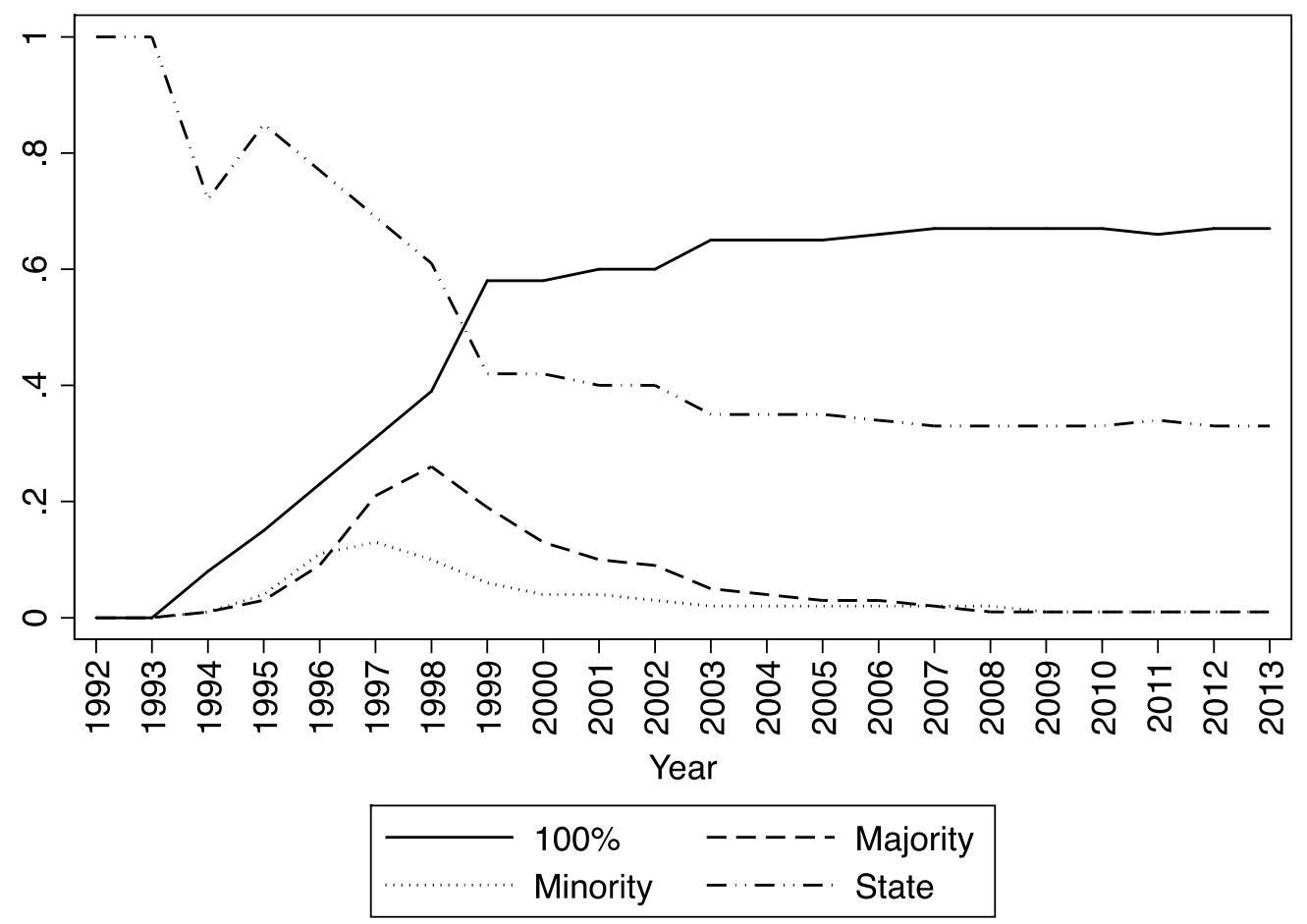

Note: $100 \%$ is 100 percent private, Majority is over 50 percent private and less than 100 percent, Minority is more than 0 percent private and less than or equal to 50 percent private, and State is 0 percent private. 
Table 4: Estimated Relative Productivity of Privatized Firms

\begin{tabular}{lccc} 
& OLS & $F E$ & FE\&FT \\
\hline Privatized & $0.119^{* *}$ & $0.102^{* *}$ & $0.054^{* *}$ \\
& $(0.022)$ & $(0.019)$ & $(0.017)$ \\
\hline $\mathrm{R}^{2}$ & 0.927 & 0.941 & 0.880 \\
\hline
\end{tabular}

Note: Estimated coefficients (standard errors) for Equation (1) in the text. OLS = ordinary least squares; FE = firm fixed effects; FE\&FT = firm fixed effects and firmspecific trends. ${ }^{* *}=$ significant at 0.01 level. The number of firm-year observations is 117,702 , and the number of firms is 9,221 . 
Table 5: Estimated Relative Productivity of Privatized Firms by Years Before/Since Privatization

\begin{tabular}{|c|c|c|c|}
\hline$\tau$ & $O L S$ & $F E$ & $F E \& F T$ \\
\hline$\leq-4$ & $\begin{array}{c}0.044 \\
(0.029)\end{array}$ & $\begin{array}{c}0.027 \\
(0.028)\end{array}$ & $\begin{array}{c}0.050 \\
(0.035)\end{array}$ \\
\hline-3 & $\begin{array}{c}0.033 \\
(0.025)\end{array}$ & $\begin{array}{l}-0.016 \\
(0.021)\end{array}$ & $\begin{array}{l}-0.001 \\
(0.026)\end{array}$ \\
\hline-2 & $\begin{array}{c}0.030 \\
(0.023)\end{array}$ & $\begin{array}{l}-0.015 \\
(0.017)\end{array}$ & $\begin{array}{l}-0.008 \\
(0.020)\end{array}$ \\
\hline-1 & $\begin{array}{c}0.044^{*} \\
(0.021)\end{array}$ & $\begin{array}{l}-0.003 \\
(0.012)\end{array}$ & $\begin{array}{c}0.004 \\
(0.013)\end{array}$ \\
\hline 1 & $\begin{array}{c}0.015 \\
(0.022)\end{array}$ & $\begin{array}{c}0.005 \\
(0.013)\end{array}$ & $\begin{array}{c}0.010 \\
(0.014)\end{array}$ \\
\hline 2 & $\begin{array}{c}0.041 \\
(0.024)\end{array}$ & $\begin{array}{c}0.039^{*} \\
(0.018)\end{array}$ & $\begin{array}{c}0.046^{*} \\
(0.020)\end{array}$ \\
\hline 3 & $\begin{array}{c}0.058^{*} \\
(0.027)\end{array}$ & $\begin{array}{c}0.071^{* *} \\
(0.023)\end{array}$ & $\begin{array}{c}0.075^{* *} \\
(0.027)\end{array}$ \\
\hline 4 & $\begin{array}{c}0.116^{* *} \\
(0.029)\end{array}$ & $\begin{array}{c}0.143^{* *} \\
(0.026)\end{array}$ & $\begin{array}{c}0.135^{* *} \\
(0.033)\end{array}$ \\
\hline 5 & $\begin{array}{c}0.140^{* *} \\
(0.031)\end{array}$ & $\begin{array}{c}0.170^{* *} \\
(0.029)\end{array}$ & $\begin{array}{c}0.152^{* *} \\
(0.038)\end{array}$ \\
\hline 6 & $\begin{array}{c}0.173^{* *} \\
(0.032)\end{array}$ & $\begin{array}{c}0.203^{* *} \\
(0.032)\end{array}$ & $\begin{array}{c}0.170^{* *} \\
(0.043)\end{array}$ \\
\hline 7 & $\begin{array}{c}0.176^{* *} \\
(0.033)\end{array}$ & $\begin{array}{c}0.210^{* *} \\
(0.034)\end{array}$ & $\begin{array}{c}0.161^{* *} \\
(0.048)\end{array}$ \\
\hline$\geq 8$ & $\begin{array}{c}0.217^{* *} \\
(0.033)\end{array}$ & $\begin{array}{c}0.266^{* *} \\
(0.036)\end{array}$ & $\begin{array}{c}0.164^{* *} \\
(0.055)\end{array}$ \\
\hline $\mathrm{R}^{2}$ & 0.925 & 0.937 & 0.878 \\
\hline
\end{tabular}

Note: Results from estimating an event-time version of Equation (1) where coefficients on privatized vary with time before or after privatization. Privatization year, defined as $\tau=0$, is the reference category. Years $\tau \leq 4$ are pooled, as are years $\tau \geq 8$. OLS = ordinary least squares; FE = firm fixed effects; FE\&FT = firm fixed effects and firmspecific trends. ${ }^{* *}=$ significant at 0.01 level; ${ }^{*}=$ significant at 0.05 level. The number of observations is 104,526 , and the number of firms is 7,664 . 
Figure 3: Estimated Relative Productivity of Privatized Firms by Years Before/Since Privatization

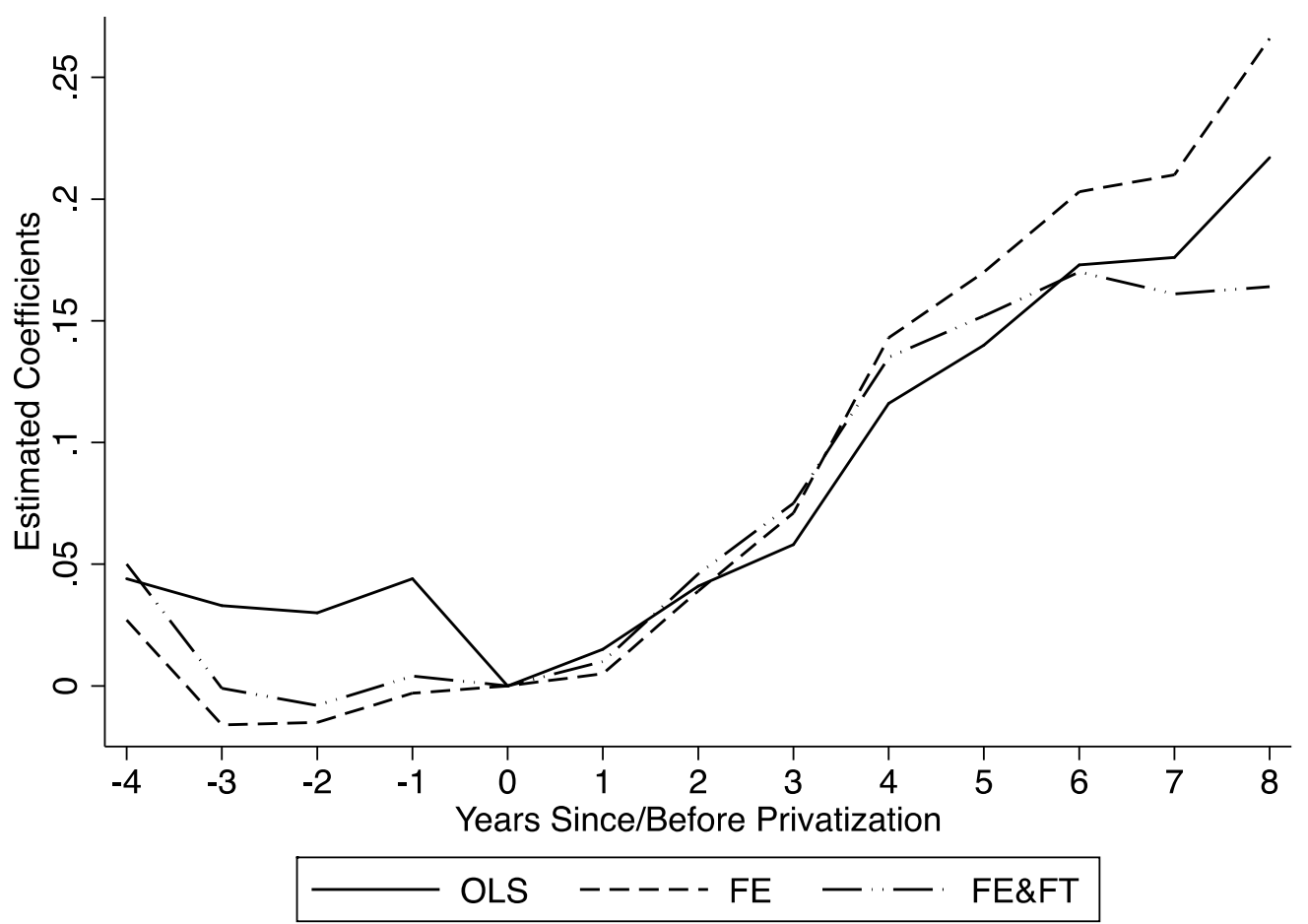

Note: This figure plots the estimated coefficients reported in Table 5. 
Table 6: Estimated Relative Productivity of Privatized Firms by Time Period

\begin{tabular}{lcc} 
& $F E$ & $F E \& F T$ \\
\hline Privatized*through 2002 & $0.049^{*}$ & $0.053^{*}$ \\
Privatized*after 2002 & $(0.018)$ & $(0.017)$ \\
& $0.271^{* *}$ & $0.159^{* *}$ \\
& $(0.033)$ & $(0.034)$ \\
\hline $\mathrm{R}^{2}$ & 0.941 & 0.880 \\
\hline
\end{tabular}

Notes: Estimates of Equation (1) where the privatized coefficient varies with calendar time: the early period is $1989-2002$, and the late period is 2003-2013. FE = firm fixed effects; FE\&FT $=$ firm fixed effects and firmspecific trends. ${ }^{* *}=$ significant at 0.01 level; ${ }^{*}=$ significant at 0.05 level. The number of firm-year observations is 117,702 , and the number of firms is 9,221 . 
Figure 4: Ukraine in Comparative Perspective: New Estimates Compared with BET (2006)

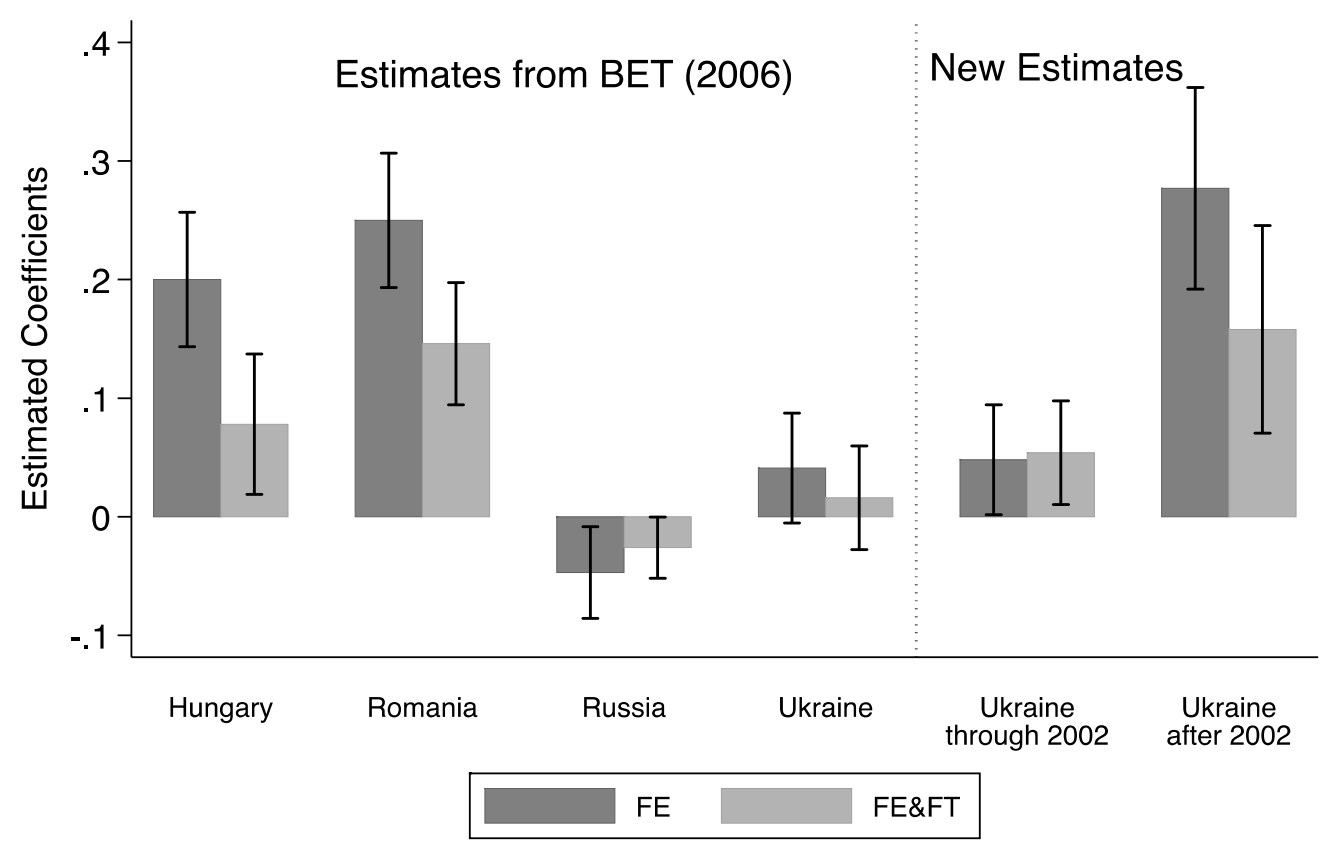

Note: The figure plots the results reported in Brown, Earle, and Telegdy (BET, 2006) for Hungary, Romania, Russia, and Ukraine using data through 2002 in the first four sets of bars, and the results from Table 6 , above, in the last two sets of bars. 
Table 7: Estimated Relative Productivity of Privatized Firms by Privatization Year

\begin{tabular}{lcc} 
& $F E$ & $F E \& F T$ \\
\hline Privatized*privatization year through 1997 & $0.126^{* *}$ & $0.060^{* *}$ \\
& $(0.021)$ & $(0.020)$ \\
Privatized*privatization year after 1997 & 0.029 & -0.004 \\
& $(0.033)$ & $(0.035)$ \\
$\mathrm{R}^{2}$ & 0.937 & 0.880 \\
\hline
\end{tabular}

Note: Estimates of Equation (1) where the privatized coefficient varies with privatization period (corresponding to a change in predominant privatization method): the early period is through 1997, and the late period is 1998 onwards. FE = firm fixed effects; FE\&FT $=$ firm fixed effects and firm-specific trends. ${ }^{* *}=$ significant at 0.01 level; *=significant at 0.05 level. The number of firm-year observations is 102,249 , and the number of firms is 7,749 . 
Table 8: Relative Survival Rate of Privatized Firms

\begin{tabular}{lc}
\hline & Probit \\
\hline Privatized & $0.256^{* *}$ \\
& $(0.015)$ \\
Never Privatized*MFP in 1992 & 0.018 \\
& $(0.018)$ \\
Privatized*MFP in 1992 & $0.028^{* *}$ \\
& $(0.001)$ \\
\hline
\end{tabular}

Note: Estimated marginal effects (evaluated at the mean of other variables) for probit regression with dependent variable $=$ survival through 2013 (mean 0.40). Never Privatized=1 for never private firms, Privatized $=1$ for ever private firms and MFP in 1992 is Multi-Factor Productivity in 1992. Sample = firms in 1992 data. ${ }^{* *}=$ significant at 0.01 level; ${ }^{*}=$ significant at 0.05 level. Number of observations $=$ 6,591 . 
Table 9: Variation of the Relative Productivity Privatization Effect by PrePrivatization Productivity

FE $\quad$ FE\&FT

Privatized

$0.103^{* *}$

$0.040^{* *}$

(0.019)

$(0.011)$

Privatized*Relative MFP in $\tau=-1$

$-0.170^{* *}-0.122^{* *}$

$(0.020) \quad(0.010)$

$\mathrm{R}^{2}$

0.942

0.883

Note: Estimation of a version of Equation (1) with an interaction between the privatized dummy and MFP in the pre-privatization year. FE = firm fixed effects; FE\&FT = firm fixed effects and firm-specific trends. ${ }^{* *}=$ significant at 0.01 level; $*=$ significant at 0.05 level. The number of observations is 103,078 , and the number of firms is 9,160 . 
Table 10: Estimated Relative Productivity of Privatized Firms: Total, Majority, and Minority Private Shares

\section{FE}

100\%*through 2002

Majority Private*through 2002

Minority Private*through 2002

Privatized*after 2002

$$
\begin{gathered}
0.065^{* *} \\
(0.021)
\end{gathered}
$$

$-0.143^{* *}$

(0.023)

$$
-0.176^{* *}
$$$$
\text { (0.026) }
$$

$0.252^{* *}$

(0.034)
FE\&FT

$$
0.071^{* *}
$$

$-0.084^{* *}$

$-0.123^{* *}$

(0.023) 0.941

$\mathrm{R}^{2}$

Note: Estimated version of Equation (1) in which the coefficient on privatized for the period through 2002 is allowed to vary between $100 \%$ and majority (but less than 100\%) private, and the majority state firms are divided between those with a minority private and those that are $100 \%$ state-owned, as in Table 3. $\mathrm{FE}=$ firm fixed effects; FE\&FT = firm fixed effects and firm-specific trends. ${ }^{* *}=$ significant at 0.01 level; ${ }^{*}=$ significant at 0.05 level. The number of firm-year observations is 117,702 , and the number of firms is 9,221 . 
Table 11: Estimated Relative Productivity of Privatized Firms: Domestic and Foreign, and Source Country of Foreign Ownership

Panel A

\begin{tabular}{lccc}
\hline & $O L S$ & $F E$ & $F E \& F T$ \\
\hline Domestic & $0.108^{* *}$ & $0.096^{* *}$ & $0.052^{*}$ \\
Foreign & $(0.022)$ & $(0.019)$ & $(0.017)$ \\
& $0.555^{* *}$ & $0.399^{* *}$ & $0.216^{* *}$ \\
& $(0.061)$ & $(0.053)$ & $(0.049)$ \\
\hline $\mathrm{R}^{2}$ & & & \\
\hline
\end{tabular}

Panel B

Domestic

$0.107^{* *}$

$0.094^{* *}$

$0.051^{* *}$

Offshore Foreign

$(0.022)$

$(0.019)$

$(0.017)$

$0.341^{* *}$

$0.215^{* *}$

0.070

Russia

(0.076)

(0.068)

(0.063)

$0.447^{* *}$

$0.257^{* *}$

$0.194 *$

$(0.090)$

(0.079)

(0.087)

Other Foreign

$0.702 * *$

$0.605^{* *}$

$0.352^{* *}$

(0.109)

(0.095)

(0.087)

$\mathrm{R}^{2}$

0.927

0.941

0.880

Note: Estimated version of Equation (1) in which the coefficient on privatized is permitted to vary between domestic and foreign ownership (in Panel A) and with type of Foreign. As described in the text, "offshore" countries include Lichtenstein, Switzerland, Republic of Moldova, Panama, OAE, Ireland, Cyprus, British Virgin Islands, Virgin Islands, Belize, Bermuda, Bahamas, Seychelles, Saint Kitts and Nevis. OLS = ordinary least squares; FE = firm fixed effects; FE\&FT = firm fixed effects and firm-specific trends. ${ }^{* *}=$ significant at 0.01 level; ${ }^{*}=$ significant at 0.05 level. The number of firm-year observations is 117,702, and the number of firms is 9,221. 


\section{Figure 5: Estimated Relative Productivity of Privatized Firms by Oblast}

\section{FE Estimates}

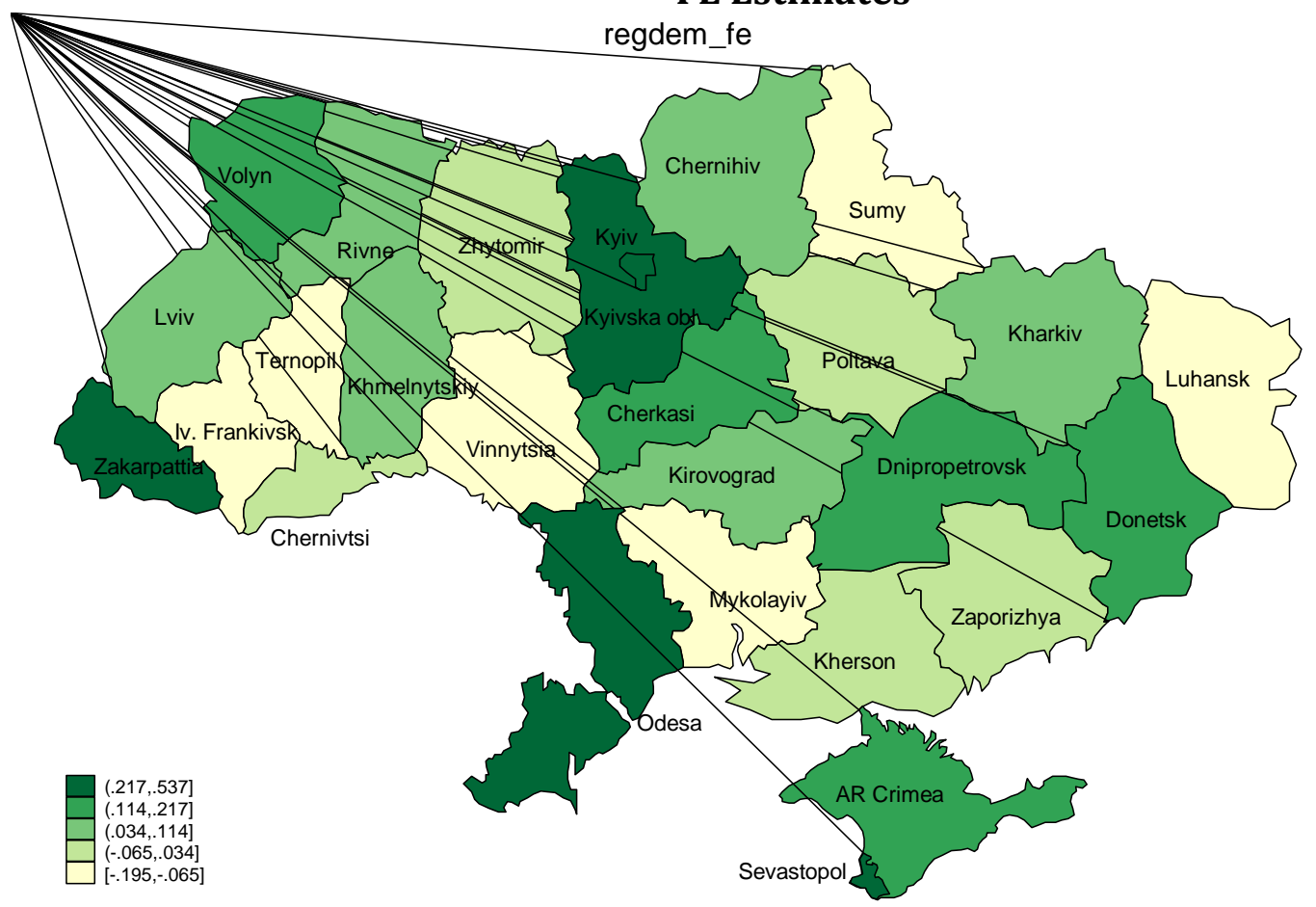

FE\&FT Estimates

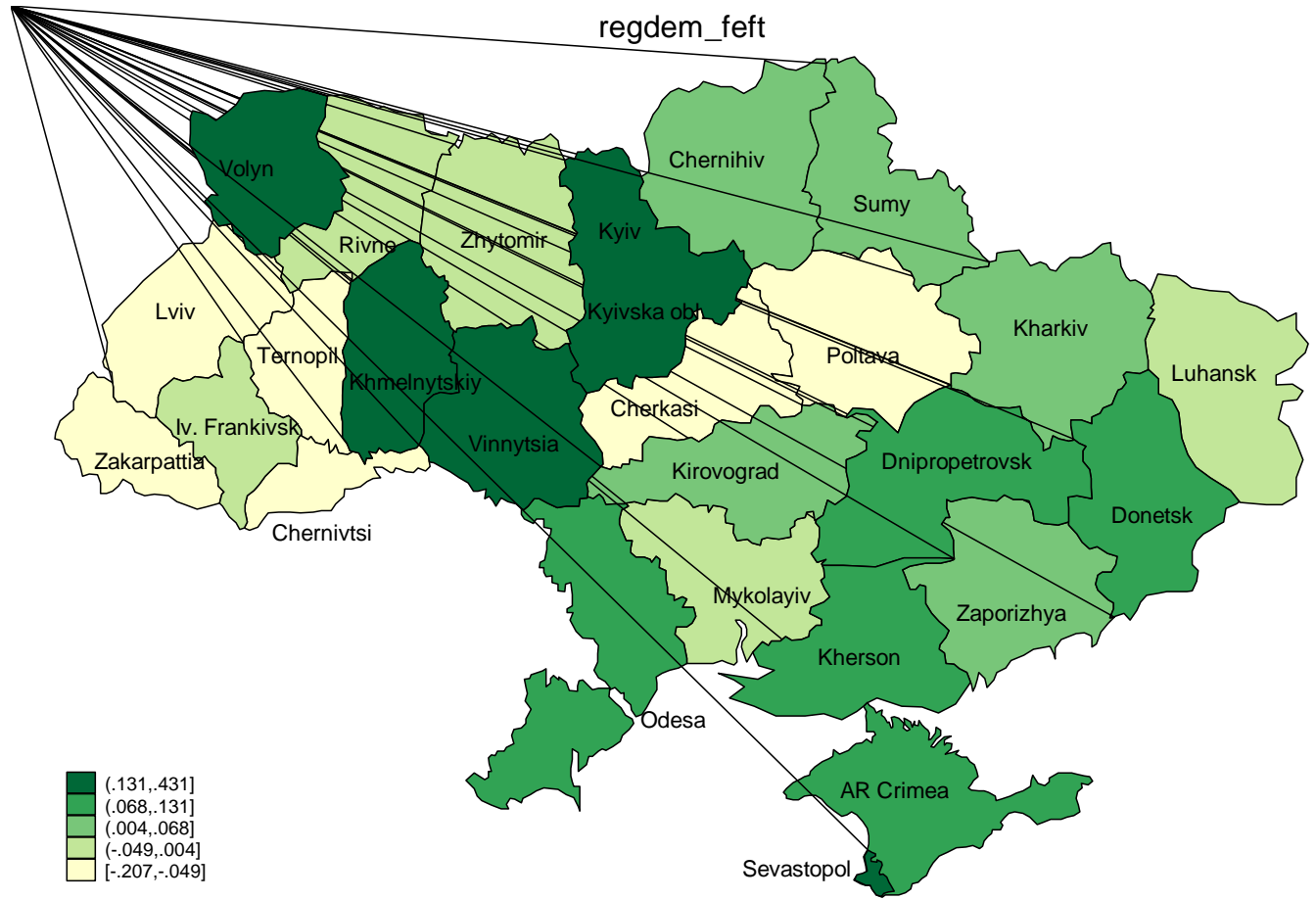

